\title{
PENGEMBANGAN MULTIMEDIA PEMBELAJARAN INTERAKTIF MATEMATIKA DALAM MENINGKATKAN PRESTASI BELAJAR SISWA SMA NEGERI 9 KOTA JAMBI
}

\author{
KASIMAN LIMBONG \\ SMA Negeri 9 Kota Jambi Provinsi Jambi \\ kasimanlimbong1994@gmail.com
}

\begin{abstract}
ABSTRAK
Tujuan penelitian ini adalah untuk menghasilkan multimedia pembelajaran interaktif matematika yang berkualitas dan layak untuk digunakan dalam pembelajaran matematika dan mendeskripsikan seberapa baik kualitas perangkat pembelajaran matematika yang dihasilkan. Kriteria kualitas yang digunakan mengacu pada kriteria Nieveen, yaitu valid, praktis dan efektif. Materi yang dikembangkan adalah materi Geometri Ruang. Jenis penelitian ini adalah penelitian pengembangan (Development research). Penelitian ini dilakukan pada semester ganjil tahun pelajaran 2019/2020. Penelitian ini mengembangkan perangkat pembelajaran matematika dengan menggunakan model pengembangan yang diadaptasi dari model pengembangan Borg \& Gall. Tahap-tahap yang dilalui sampai diperoleh multimedia pembelajaran matematika yang valid, praktis dan efektif adalah analisis kebutuhan dan perumusan tujuan, desain/pengembangan produk, uji coba, revisi dan kajian produk akhir. Uji coba yang dilakukan meliputi ujicoba ahli/validasi ahli (expert judgement), uji coba kelompok kecil (small group try-out) dan uji coba lapangan (field try-out). Uji coba lapangan (field tryout) dilakukan pada dua kelas XII IPS 3 \& 4 di SMA Negeri 9 Kota Jambi tahun pelajaran 2019/2020. Instrumen penelitian yang digunakan adalah lembar validasi, lembar penilaian guru, lembar penilaian siswa, angket motivasi dan tes hasil belajar. Penelitian ini menghasilkan multimedia pembelajaran matematika yang berkualitas dan layak. Hasil penelitian menunjukkan bahwa multimedia pembelajaran matematika yang dikembangkan valid, praktis dan efektif.
\end{abstract}

Kata Kunci: multimedia pembelajaran interaktif, matematika, prestasi belajar

\section{PENDAHULUAN}

Peran pendidikan amat menentukan bagi perkembangan kualitas sumber daya manusia, terutama bagi pembangunan bangsa dan Negara untuk dapat bersaing menghadapai tuntutan perkembangan zaman. Kuswana (2011: 204) menyatakan bahwa pengertian belajar haruslah sesuai dengan konvensi pada zamannya. Situasi demikian mengharuskan kegiatan belajar cocok dengan zamannya. Belajar merupakan kegiatan suatu tugas dari paling sederhana menuju tugas paling sulit yang bersifat hierarkis, guna membantu cara berpikir terstruktur.

Pembelajaran memiliki karakteristik proses mental dan proses konstruktivisme dalam membangun pengetahuan (Sagala, 2010:63). Proses tersebut merupakan peristiwa mencampur, mencocokkan, menggabungkan, menukar, dan mengurutkan konsep-konsep, persepsi-persepsi, dan pengalaman sebelumnya. Pembelajaran secara sederhana pada dasarnya adalah melakukan suatu usaha eksplorasi dan memindahkan pengetahuan yang bermakna dari sumber belajar untuk pengembangan berikutnya.

Proses-proses pemahaman matematik sejalan dengan apa yang telah dikembangkan oleh Piaget (Ruseffendi, 1988:133), yaitu mengenai proses seorang anak belajar melalui pengalamannya. Matematika bukanlah barang baru bagi manusia. Peran unik sebagai pionir jalan bagi masa depan teknologi telah mengantarnya sebagai ilmu yang wajib hukumnya untuk dipelajari bagi semua kalangan manusia. Manusia lebih mengenalnya sebagai alat bantu untuk mempermudah kegiatan perhitungan dari pada sebagai perangkat dalam proses berpikir logis yang dapat bekerja dalam ranah sosial (Syarifah, 2017). Sifat yang strategis tersebut yang menjadikan matematika sebagai ilmu tingkat tinggi yang tidak semua orang mudah untuk menguasainya. Alt, dkk (2014) melakukan penelitian bahwa matematika berkaitan erat dengan 
bahasa. Pernyataan tersebut berarti bahwa dalam proses kegiatan matematika memerlukan bagian-bagian yang berbeda namun kesemuanya saling menunjang satu sama lain untuk mendapatkan suatu produk matematika yang baik. Pernyataanlah yang menegaskan suatu tahapan dalam kegiatan matematika dapat menjadi konsisten. Pemahaman matematis merupakan dan tujuan dari suatu proses pembelajaran matematika di Sekolah Menengah Atas (SMA). Pemahaman matematis sebagai suatu tujuan, berarti suatu kemampuan memahami konsep, membedakan sejumlah konsep-konsep yang saling terpisah, serta kemampuan melakukan perhitungan secara bermakna pada situasi atau permasalahan- permasalahan yang lebih luas (Purnama, 2020).

Guru sebagai pengajar, idealnya harus mampu mengelola proses pembelajaran yang dapat memotivasi siswa, kreatif dan selalu berinovasi dalam menyediakan bahan dan media belajar bagi siswa. Hal ini jelas sangat diperlukan apalagi dalam pembelajaran matematika, dimana kebanyakan siswa cepat jenuh mengikuti proses pembelajaran. Oleh karena itu, media pembelajaran sangat dibutuhkan untuk menunjang proses perkembangan kognitif siswa. Sama halnya dalam pembelajaran matematika, media dibutuhkan sebagai alat komunikasi antara guru dan murid untuk memperjelas konsep yang bersifat abstrak. Salah satu aspek yang harus diperhatikan dalam memilih dan menggunakan media pembelajaran adalah tentang modalitas belajar anak (Musfiqon, 2012: 13). Modalitas belajar merupakan potensi dasar atau kecenderungan yang dimiliki anak. Dengan modalitas belajar siswa yang variatif, seharusnya pemilihan media pembelajaran dari seorang guru tidak hanya terfokus pada salah satu modalitas saja, seperti yang pada umumnya terjadi. Jika ditinjau dari hal tersebut, maka seorang guru perlu mengombinasikan berbagai media dalam menyampaikan pesan sehingga pembelajaran akan lebih optimal. Perpaduan antara berbagai media sering disebut sebagai konsep multimedia (Sugianto, dkk, 2013).

Untuk menghilangkan rasa jenuh dalam belajar dan menumbuhkan minat peserta didik dalam mata pelajaran matematika maka harus ada terobosan baru dalam kegiatan belajar di kelas. Mengembangkan dan memanfaatkan media atau alat peraga yang telah hadir di sekeliling kita, bisa menjadi salah satu alternatif yang bisa dilakukan guru atau pelaku pendidikan agar kegiatan belajar mengajar lebih baik lagi dan tepat sasaran, yaitu salah satunya dengan multimedia (Suseno, 2020). Dengan bantuan multimedia dalam kegiatan belajar mengajar maka akan membuat peserta didik lebih jelas dengan melihat dimensi-dimensi yang disajikan dalam multimedia visual sehingga peserta didik akan lebih bersemangat untuk melakukan kegiatan belajar mengajar di sekolah (Andiny, 2016). Matematika sulit bahkan menjadi fobia, lebih disebabkan pola pengajaran konvensional yang proses belajar-mengajarnya lebih mene- kankan pada ceramah guru, mengerjakan soal, hafalan dan kecepatan berhitung sehingga siswa kurang membuka wawasan pengetahuan, dapat menyebabkan siswa menjadi pasif sehingga siswa kurang paham dengan apa yang dipelajarinya yang dalam hal ini tidak memiliki pemahaman terhadap konsep yang diajarkan. Siswa cende- rung malas dan memiliki motivasi yang rendah untuk belajar matematika baik secara klasikal maupun untuk belajar mandiri di rumah.

Darhim (2012) menyatakan walaupun hasil ujian nasional tergolong baik, tetapi berdasarkan evaluasi Internasional siswa kita menunjukkan prestasi matematika yang kurang menggembirakan. Potensi besar yang dimiliki siswa Indonesia hampir belum dikembangkan untuk mengapai sesuai harapan. Gambaran kemampuan siswa tersebut erat kaitannya dengan kemampuan guru dalam mengelola pembelajaran matematika. Patut diduga ada korelasi antara kemampuan siswa dan kemampuan gurunya (Surya, 2013).

Berdasarkan penggalian data yang dilakukan oleh peneliti, diperoleh fakta bahwa Hasil UN di SMA Negeri 9 Kota Jambi menunjukkan bahwa materi Geometri ruang merupakan materi yang berdaya serap rendah. Selain itu, hasil ulangan harian yang dilakukan di kelas XII IPS 3 \& 4 SMA Negeri 9 Kota Jambi terhadap materi geometri ruang pada tahun ajaran 2019/2020 menunjukkan bahwa terdapat 82,61\% siswa atau 57 dari 69 siswa belum mencapai kriteria ketuntasan minimal (KKM) yaitu 70. Hal ini menunjukkan bahwa materi geometri ruang merupakan salah satu materi dalam pelajaran matematika yang tergolong sulit. Hasil ini 
mengindikasikan perlunya diteliti faktor-faktor apa yang menjadi penyebab rendahnya pencapaian kompetensi pada materi geometri ruang di SMA Negeri 9 Kota Jambi. Rendahnya pencapaian kompetensi siswa pada materi tersebut ber-pengaruh pada rendahnya prestasi belajar siswa dan minat siswa terhadap materi tersebut pun rendah (Tiurma, dkk, 2014).

Adapun prestasi belajar berhubungan dengan tingkah laku, hasil, sikap, dan watak (Jhonson, et, al, 2002: 8). Prestasi belajar juga berhubungan dengan hasil belajar yang menampilkan pemahaman dan penguasaan bahan pelajaran (Hudojo, 1988: 144). Dalam hal ini, prestasi belajar dapat dilihat dari nilai KKM yang sudah ditetapkan sekolah. Nilai 70 merupakan nilai KKM yang sudah ditetapkan sekolah SMA Negeri 9 Kota Jambi untuk pelajaran matematika.

Oleh karena itu perlu dikembangkan suatu multimedia pembelajaran matematika yang memuat materi geometri ruang. Hal ini dikarenakan Multimedia pembelajaran matematika tentang materi geometri ruang masih sangat jarang ditemukan. Hal ini mungkin yang menjadi salah satu faktor penyebab pembelajaran matematika pada materi geometri ruang kurang maksimal. Banyak topik dalam materi geometri ruang yang perlu disampaikan secara interaktif dan melibatkan partisipasi aktif dari siswa sehingga pembelajaran lebih melekat dalam diri siswa. Kedudukan media pembelajaran dalam pembelajaran matematika sebagai salah satu upaya untuk mempertinggi proses interaksi guru-siswa dan interaksi siswa dan lingkungan belajar matematika. Fungsi media pembelajaran adalah sebagai alat bantu mengajar, yakni menunjang penggunaan metode mengajar yang dipergunakan guru. Pengembangan Multimedia pembelajaran Interaktif menjadi hal yang strategis karena memiliki potensi besar untuk merangsang siswa supaya dapat merespons positif materi pembelajaran yang disampaikan (Wahyuni, 2019).

Pembelajaran interaktif dengan media komputer memiliki beberapa keuntungan, salah satunya adalah mampu meningkatkan kemampuan siswa dalam matematika, kecepatan siswa dalam penguasaan konsep yang dipelajarinya lebih tinggi, retensi siswa lebih lama, dan sikap siswa terhadap matematika menjadi semakin positif. Dalam pembelajaran matematika interaktif, bahan ajar dibuat dalam desain khusus sehingga interaksi antar siswa dan komputer berlangsung secara dinamis dalam bentuk stimulus-respon. Komputer memberi kesempatan kepada siswa untuk memberikan input yang direspon komputer atau sebaliknya. Dalam proses berikutnya respon bisa dijadikan sebagai stimulus baru sehingga dimungkinkan adanya respon lanjutan yang akan memperkuat konsep dan daya ingat siswa (Hakim, dkk, 2016).

\section{METODE PENELITIAN}

Penelitian ini merupakan penelitian pengembangan (Research and Development). Menurut Gay (1981: 10) penelitian pengembangan adalah suatu usaha untuk mengembangkan suatu produk yang efektif berupa materi pelajaran, media dan strategi pembelajaran untuk digunakan di kelompok belajar. Penelitian pengembangan bukan untuk menguji teori. Dengan kata lain penelitian pengembangan adalah suatu proses yang digunakan untuk mengembangkan atau menvalidasi produk-produk yang digunakan dalam pendidikan dan pembelajaran.

Penelitian ini difokuskan pada pengembangan produk berupa multimedia pembelajaran interaktif matematika pada materi pokok geometri ruang. Model pengembangan multimedia pembelajaran yang digunakan dalam penelitian ini menggunakan langkah-langkah yang diadaptasi dari model Borg \& Gall (1983, p.775). Langkah-langkah tersebut terbagi ke dalam tiga tahapan, yaitu 1) tahap pendahuluan, 2) tahap pengembangan, dan 3) tahap validasi. Pada tahap pendahuluan terdapat tiga langkah, tahap pengembangan terdapat empat langkah, dan tahap validasi terdapat 3 langkah. Langkah-langkah tersebut terbagi ke dalam tiga tahapan, yaitu tahap pendahuluan, tahap pengembangan, dan tahap validasi.

Pada peneltian ini dilakukan ujicoba yang berfungsi untuk mengetahui kelayakan dari produk multimedia pembelajaran yang dikembangkan. Adapun tahapan yang dilalui adalah: (a) validasi oleh ahli, (b) analisis konseptual, (c) revisi I, (d) evaluasi kelompok kecil, (e) analisis 
hasil evaluasi kelompok kecil, (f) revisi II, (g) uji coba lapangan, (h) analisis hasil uji coba lapangan, (i) revisi III, dan (j) produk akhir.

Ujicoba dilakukan sebanyak 2 kali, yaitu uji coba kelompok kecil dan ujicoba kelompok besar. Responden uji coba kelompok kecil adalah 12 orang siswa yang diambil dari kelas XII IPS 3 \& 4 SMA Negeri 9 Kota Jambi yang mewakili kelompok dengan kemampuan tinggi, sedang dan kurang. Responden uji coba lapangan berjumlah 69 orang siswa XII IPS 3 \& 4 SMA Negeri 9 Kota Jambi. Instrumen yang digunakan untuk mengumpulkan data pada penelitian ini adalah: (1) angket untuk ahli materi dan pembelajaran, dan ahli media, (2) angket kualitas teknis, (3) angket untuk motivasi siswa, dan (4) tes hasil belajar siswa.

Analisis terhadap keefektifan multimedia pembelajaran matematika dilakukan terhadap data hasil tes prestasi belajar yang diperoleh oleh siswa. Produk dikatakan efektif ditinjau dari motivasi siswa jika terdapat peningkatan skor motivasi siswa dari sebelum dilakukan pembelajaran dan sesudah dilakukan pembelajaran menggunakan multimedia pembelajaran matematika yang dikembangkan. Produk dikatakan efektif ditinjau dari prestasi belajar siswa jika minimal $80 \%$ siswa mencapai skor 70 .

\section{HASIL DAN PEMBAHASAN \\ Prosedur Pengembangan}

Tahap pertama yaitu menganalisis standar kompetensi menggunakan geometri ruang dalam pemecahan masalah yang berkaitan dengan jarak antara dua titik dalam ruang untuk disampaikan melalui multimedia pembelajaran. Proses ini meliputi kajian materi matematika yang sesuai dengan standar isi.

Tahap kedua mengumpulkan referensi mengenai materi pokok geometri ruang . Pemilihan materi geometri ruang karena pada materi tersebut tersebut hasil belajar siswa masih banyak yang masih dibawah KKM. Selain itu, nilai ujian nasional (UN) di SMA Negeri 9 Kota Jambi pada standar kompetensi tersebut selama tiga tahun terakhir mengalami penurunan (laporan BSNP).

Pembuatan multimedia pembelajaran ini membahas tentang standar kompetensi menggunakan geometri ruang dalam pemecahan masalah yang berkaitan dengan jarak antara dua titik dalam ruang. Standar kompetensi tersebut memuat 2 kompetensi dasar, yaitu (1) Mendeskripsikan jarak dalam bangun ruang (antartitik, titik ke garis, dan titik ke bidang ), (2) Menentukan jarak dalam bangun ruang (antar titik, titik ke garis, dan titik ke bidang, garis ke bidang dan bidang dengan bidang ). (3) Tahap ketiga merencanakan dan memilih jenis media pembelajaran yang akan digunakan. Multimedia pembelajaran yang dipilih yaitu berupa CD pembelajaran yang dapat digunakan dengan perangkat komputer. Pemilihan ini dikarenakan pengemasan dalam bentuk CD sangat efektif karena mempunyai memori yang cukup besar dan tidak mudah terhapus.

Tahap keempat pembuatan multimedia pembelajaran ini membahas tentang materi pokok geometri ruang. Tahap ini merupakan desain awal pembuatan multimedia pembelajaran matematika yang dikembangkan. Desain tersebut menggambarkan alur halaman yang tersedia pada multimedia mulai dari halaman pembuka hingga halaman penutup. Pembuatan multimedia pembelajaran matematika mengacu pada desain ini.

Tahap kelima melakukan validasi multimedia pembelajaran yang telah direvisi kepada ahli materi dan pembelajaran, ahli media, dan siswa (kelas besar dan kelas kecil) disertai instrumen penilaian kesesuaian media pembelajaran. Alur validasi multimedia pembelajaran dapat dilihat pada Gambar 1 berikut: 


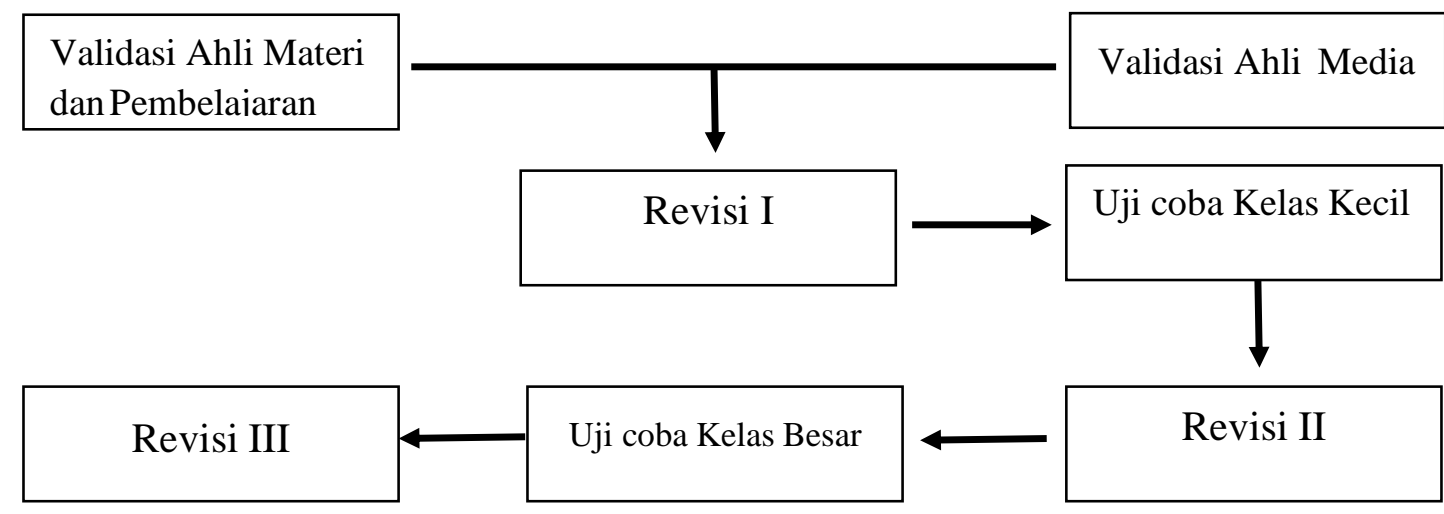

Gambar 1. Alur Validasi Multimedia Pembelajaran

Multimedia pembelajaran divalidasi terlebih dahulu oleh ahli materi dan pembelajaran, dan ahli media. Setelah mendapat masukan dari ahli materi dan pembelajaran serta ahli media kemudian multimedia pembelajaran direvisi untuk medapatkan revisi I. Setelah multimedia pembelajaran dinyatakan sudah layak untuk digunakan kemudian multimedia pembelajaran diujicobakan kepada kelas kecil. Setelah menda- pat masukan dari siswa pada kelas kecil kemudian multimedia pembelajaran direvisi untuk mendapatkan revisi II. Setelah mendapatkan revisi II kemudian multimedia pembelajaran diujicobakan kepada kelas besar. Setelah diuji- cobakan dan mendapatkan masukan dari siswa pada kelas besar kemudian multimedia di revisi untuk mendapatkan revisi III.

Untuk menganalisis kevalidan produk digunakan dua data, yaitu penilaian ahli materi dan pembelajaran matematika, dan penilaian ahli media terhadap multimedia pembelajaran matematika. Data skor kevalidan multimedia pembelajaran matematika dapat dilihat pada Tabel 1 .

Tabel 1. Data Skor Kevalidan Multimedia Pembelajaran Matematika
\begin{tabular}{cccc}
\hline No & Aspek & Skor & Kategori \\
\hline 1 & Materi \& Pembelajaran & 60,33 & Sangat Baik \\
2 & Media & 39 & Sangat Baik \\
\hline
\end{tabular}

Skor yang diperoleh untuk kevalidan produk dari aspek materi dan pembelajaran matematika yaitu 60,33 yang berada pada ren- tang skor di atas 56 sehingga kevalidan produk dari aspek materi dan pembelajaran matematika termasuk kategori sangat baik. sedangkan skor kevalidan yang diperoleh dari aspek media yaitu 39 yang berada pada rentang 36, sehingga kevalidan produk dari aspek media termasuk dalam kategori sangat baik. Penilaian kevalidan produk dari ahli materi dan pembelajaran dan ahli media secara konsisten menyatakan sangat baik.

Penilaian kevalidan produk dari ahli materi dan pembelajaran dan ahli media secara konsisten menyatakan sangat baik. Oleh karena itu, dari data yang diperoleh dari penilaian oleh ahli materi dan pembelajaran matematika, dan ahli media dapat disimpulkan bahwa produk yang dikembangkan yaitu berupa multimedia pembelajaran matematika dapat dinyatakan sangat valid sehingga layak digunakan.

Untuk mengetahui kepraktisan produk yang dikembangkan data yang digunakan adalah data tentang penilaian guru dan siswa terhadap multimedia pembelajaran matematika. Data skor kepraktisan siswa dapat dilihat pada tabel 2 berikut:

Tabel 2. Data Skor Kepraktisan

\begin{tabular}{cccc}
\hline No & Penilai & Skor & Kategori \\
\hline 1 & Siswa & 201,6 & Sangat Baik \\
2 & Guru & 7,1 & Baik \\
\hline
\end{tabular}


Kepraktisan produk berdasarkan penilaian siswa yaitu 201,6 yang berada pada rentang skor di atas 196 sehingga kepraktisan produk berdasarkan penilaian siswa termasuk kategori sangat baik. sedangkan skor kepraktisan yang diperoleh dari penilaian guru yaitu 7,1 yang berada pada rentang 6,7-8, sehingga kepraktisan produk berdasarkan penilaian guru termasuk dalam kategori baik. Penilaian kepraktisan produk dari siswa dan guru secara konsisten menyatakan baik.

\section{Analisis Keefektifan Multimedia Pembelajaran Interaktif Matematika}

Keefektifan ditinjau dari prestasi belajar siswa. Prestasi belajar dilihat berdasarkan tes hasil belajar siswa. Berdasarkan data tes hasil belajar yang diperoleh oleh siswa hasil belajar dari kedua kelas, yaitu kelas XII IPS 3 dan XII IPS 4 diperoleh hasil analisis seperti pada Tabel 3 berikut:

Tabel 3. Data Ketuntasan Hasil Belajar

\begin{tabular}{cccc}
\hline No & Kelas & Jumlah siswa & Ketuntasan (\%) \\
\hline 1 & XA & 34 & $91,30 \%$ \\
2 & XB & 35 & $73,07 \%$ \\
& Total & $\mathbf{6 9}$ & $\mathbf{8 1 , 6 3 \%}$ \\
\hline
\end{tabular}

Persentase ketuntasan siswa yaitu $81,63 \%$. Hal ini menunjukkan bahwa ketuntasan individu siswa telah mencapai batas minimum ketuntasan yaitu $80 \%$. Sehingga dapat disimpulkan bahwa produk yang dikembangkan efektif ditinjau dari prestasi belajar siswa. Berdasarkan data yang diperoleh dari ha- sil tes prestasi belajar siswa yang menunnjukkan bahwa lebih dari 75\% siswa mencapai kriteria ketuntasan minimal (KKM).

\section{Kajian Produk Akhir}

Setelah dilakukan serangkaian tahap pengembangan, diperoleh produk akhir yang berupa multimedia pembelajaran matematika yang memuat standar kompetensi menggunakan geometri ruang untuk memecahkan permasalahan yang berkaitan dengan jarak dalam ruang. Produk tersebut telah dinyatakan valid, praktis, dan efektif melalui analisis yang dilakukan terhadap data- data yang diperoleh.

Produk yang dikembangkan ini telah melalui proses validasi dan penilaian dengan melakukan revisi sebanyak 3 kali. Multimedia pembelajaran matematika ini juga ditujukan untuk meningkatkan prestasi belajar siswa dalam belajar matematika. Kualitas produk yang dikembangakan juga dinyatakan sangat baik berdasarkan penilai ahli materi dan pembelajaran matematika, ahli media dan siswa sehingga layak digunakan untuk skala yang lebih besar.

Produk ini dirancang sebagai media pembelajaran yang dapat digunakan guru untuk menyampaikan materi di kelas. Adapun metode yang digunakan pada saat ujicoba produk adalah direct instruction (pengajaran langsung). Pemilihan metode direct instruction ini dikarenakan produk dirancang sebagai media pembelajaran yang membantu guru menyampaikan materi geometri ruang. Selain itu metode ini dirasa efektif dan efisien digunakan pada pembelajaran matematika yang menggunakan multimedia pembelajaran matematika.

\section{KESIMPULAN}

Produk yang dikembangkan berupa multimedia pembelajaran interaktif matematika tentang materi pokok geometri ruang. Multimedia pembelajaran interaktif matematika memuat 7 sub-bab yaitu tokoh matematika, kedudukan titik, garis dan bidang dalam ruang, jarak dua titik dalam ruang, jarak titik dengan garis dalam ruang, jarak titik dengan bidang, jarak garis dengan bidang dan jarak bidang dengan bidang dalam ruang. Selain itu multimedia pembelajaran interaktif matematika juga menyediakan latihan-latihan soal yang interaktif yang memudahkan siswa mempelajari materi geometri ruang. Produk ini telah diujicobakan di SMA 
Negeri 9 Kota Jambi sehingga layak digunakan dalam kegiatan pembelajaran dengan skala yang lebih luas.

Penelitian pengembangan ini menghasilkan produk berupa multimedia pembelajaran interaktif matematika yang sangat valid, praktis dan efektif ditinjau dari motivasi dan prestasi belajar siswa. Beberapa keterbatasan yang terdapat pada peneltian ini yaitu pengembangan multimedia pembelajaran interaktif matematika hanya dilakukan untuk materi geometri ruang saja dikarenakan keterbatasan waktu penelitian. Selain itu, tahap pengembangan belum sampai pada tahap diseminasi produk dikarenakan keterbatasan waktu dan biaya yang dimiliki oleh peneliti. Ujicoba produk hanya dilakukan pada satu sekolah saja. Hal ini dikarenakan masih terbatasnya jumlah sekolah-sekolah yang mempunyai sarana dan prasarana yang memadai untuk melaksanakan pembelajaran matematika menggunakan multimedia pembelajaran interaktif matematika.

\section{DAFTAR PUSTAKA}

Alt, Mary. Genesisi D. Arizmendi. Carole R. Beal. 2014. The Relation between Mathematics Languange: "Academic Implications Children with Specific Languange Impairment and English Languane Learners." Languange, Speech, And Hearing Service in School, Vol. 45: 220-233.

Andinny, Y., \& Lestari, I. (2016). Pengaruh pembelajaran multimedia terhadap hasil belajar matematika. JKPM (Jurnal Kajian Pendidikan Matematika), 1(2), 169-179.

Darhim, 2012. Guru Matematika: Ilmuwan, Siswa, Profesional. Harian Seputar Indonesia halaman 11. Pidato Disampaikan pada Pengukuhan Guru Besar UPI Bandung, di Bandung, tanggal 26 April 2012.

Hakim, A. R., \& Windayana, H. (2016). Pengaruh penggunaan multimedia interaktif dalam pembelajaran matematika untuk meningkatkan hasil belajar siswa SD. EduHumaniora| Jurnal Pendidikan Dasar Kampus Cibiru, 4(2).

Hudojo, H. (1988). Mengajar Belajar Matematika. Jakarta: Departemen Pendidikan dan Kebudayaan, Direktorat Jenderal Pendidikan.

Johnson, D. W., \& Johnson, R. T. (2002). Meaningful assessment: A manageable and cooperative process. Pearson College Division.

Kuswana, WS. (2011). Taksonomi Berpikir. Bandung: PT. Remaja Rosdakarya.

Purnama, A., Wijaya, T. T., Dewi, S. N., \& Zulfah, Z. (2020). Analisis buku siswa matematika sma dari indonesia dan china pada materi peluang dan statistik. Jurnal Cendekia: Jurnal Pendidikan Matematika, 4(2), 813-822.

Ruseffendi, E.T. (1988). Pengantar Kepada Membantu Guru mengembangkan Kompetensinya dalam Pengajaran Matematika untuk Meningkatkan CBSA. Bandung: Tarsito.

Sagala, Syaiful. (2010). Konsep dan Makna Pembelajaran. Bandung: Alfabeta.

Sugianto, D., Abdullah, A. G., Elvyanti, S., \& Muladi, Y. (2013). Modul virtual: Multimedia flipbook dasar teknik digital. Invotec, 9(2).

Surya, E. (2013). Analisis Pemetaan dan Pengembangan Model Pembelajaran Matematika SMA di Kabupaten Tapteng dan Kota Sibolga Sumatera Utara. Jurnal Paradikma, 6(1), 75-88.

Suseno, P. U., Ismail, Y., \& Ismail, S. (2020). Pengembangan Media Pembelajaran Matematika Video Interaktif berbasis Multimedia.Jambura Journal of Mathematics Education, 1(2), 59-74.

Syarifah, L. L. (2017). Analisis kemampuan pemahaman matematis pada mata kuliah pembelajaran matematika SMA II. JPPM (Jurnal Penelitian dan Pembelajaran Matematika), 10(2).

Tiurma, L., \& Retnawati, H. (2014). Keefektifan pembelajaran multimedia materi dimensi tiga ditinjau dari prestasi dan minat belajar matematika di SMA. Jurnal Kependidikan: Penelitian Inovasi Pembelajaran, 44(2). 
TEACHER : Jurnal Inovasi Karya Ilmiah Guru Vol. 1 No. 1 September 2021, e-ISSN : 2807-8667| p-ISSN : 2807-8837

Wahyuni, D. (2019). Pengembangan multimedia pembelajaran matematika dengan pendekatan matematika realistik (Doctoral dissertation, UIN Raden Intan). 